\title{
Diabetes in Tribes of India: A literature review
}

\author{
Arun Kumar, Manohar Bhatia, Pawan Kumar Goel, Ram Bilas Jain ${ }^{1}$ \\ Department of Community Medicine, Shaheed Hasan Khan Mewati Government Medical College, Nalhar, Mewat, ${ }^{1}$ Department of Community \\ Medicine, Pandit Bhagwat Dayal Sharma Post Graduate Institute of Medical Sciences, Rohtak, Haryana, India
}

\section{A B S T R A C T}

Diabetes mellitus (DM), commonly regarded as a lifestyle disease, used to be a disease of affluent societies in the days of yore. However, now it has encroached into the rural and tribal communities as well.This narrative review provides us with an understanding of the epidemiology of diabetes burden in tribes of India.Around I $5 \%$ of the country's area is covered by tribals and it constitutes $\sim 8.6 \%$ (i.e., $\sim 104$ million) of India's total population. Prevalence of diabetes in tribal areas ranges from around $1 \%$ to $10 \%$. Hence, intensive efforts directed towards filling the gaps in awareness levels and the operational research or other data gaps would help prevent and control the problem of diabetes and fill these gaps in tribal areas.

Key words: Diabetes, health programs, India, prevalence, tribe

\section{INTRODUCTION}

Diabetes mellitus (DM), commonly regarded as a lifestyle disease, used to be a disease of affluent societies in the days of yore. However, now it has encroached into the rural and tribal communities as well. Census 2011 data shows low literacy rates among tribal populations which could expectedly be positively correlated with the less awareness levels about the disease prevention and healthy behaviors. ${ }^{[1]}$ People in the tribal areas might not be even aware of the free services or facilities being provided to them. A review of the epidemiology of the diabetes problem in the tribal areas of the country would help solving this public health problem in a more efficient way. Hence, we reviewed the available literature to understand the epidemiology of diabetes burden in tribes of India.

\section{GEOGRAPHY OF TRIBES}

Around $15 \%$ of the country's area is covered by tribals. If we look at the population composition, they constitute around $8.6 \%$ (i. e., $\sim 104$ million) of India's total population. ${ }^{[2,3]}$

\begin{tabular}{|l|l|}
\hline \multicolumn{2}{|c|}{ Access this article online } \\
\hline Quick Response Code: & Website: \\
\hline & www.josh.net \\
\hline & \\
\hline
\end{tabular}

The population of scheduled tribes had increased at a growth rate of $23.66 \%$ during the period 2001-2011. More than half the tribal population is confined to the states of Madhya Pradesh, Maharashtra, Odisha, Rajasthan, Gujarat, Jharkhand, and Chhattisgarh. The highest percentage of tribal population is in Mizoram (94.43\%), while the lowest is in Uttar Pradesh (0.57\%). Tribal population percentage higher than the national average of the $8.6 \%$, is distributed to the 20 states and 2 union territories (UTs). ${ }^{[4]}$ Tribal populations lag far behind the general population in accessibility to the essential care. Besides less participation, the low socioeconomic status adds to the need of special healthcare for this demographic segment of the population.

\section{EPIDEMIOLOgY OF DIABETES IN TRIBES}

A study in Telangana which compared the diabetic and prediabetic status of tribal and nontribal populations

This is an open access article distributed under the terms of the Creative Commons Attribution-NonCommercial-ShareAlike 3.0 License, which allows others to remix, tweak, and build upon the work non-commercially, as long as the author is credited and the new creations are licensed under the identical terms.

For reprints contact: reprints@medknow.com

How to cite this article: Kumar A, Bhatia M, Goel PK, Jain RB. Diabetes in Tribes of India: A literature review. J Soc Health Diabetes 2016;4:41-3.

Corresponding Author: Dr. Arun Kumar, Department of Community Medicine, Shaheed Hasan Khan Mewati Government Medical College, Nalhar, Mewat, Haryana, India. E-mail: arun.pgims@gmail.com 
showed the prevalence of diabetes among tribals to be almost similar to that in the rural areas, while the prediabetic status was high and fast approaching semiurban status. The numbers detected to be diabetics are $4.13 \%$ in tribal and $8.8 \%$ in nontribal groups. The total number of diabetics detected in these areas is $4.95 \%$, while $11.57 \%$ were in the prediabetic state. ${ }^{[5]} \mathrm{A}$ study was carried out in Himachal Pradesh among 8,000 tribal individuals out of which 4,000 were living in tribal areas and 4,000 had migrated to urban areas. Overall, in tribes of urban areas the prevalence of central obesity $(59.0 \%)$, overweight (29.3\%), and DM (fasting: $7.8 \%$; oral glucose tolerance test (OGTT): $8.5 \%$ ) was significantly higher than that in other tribal areas. Based on OGTT, the prevalence of DM was found to be $9.2 \%$ among central obese tribal people of urban area and $6.7 \%$ of other tribal area. DM had shown a significantly high prevalence among the urban tribes. ${ }^{[6]}$ Another study carried out in the Jhunjhunu district of Rajasthan showed the crude prevalence of type 2 diabetes was $5.2 \%$ among tribal population and $0.7 \%$ in nontribal subjects. The risk for diabetes was found to be equal in both tribesmen $(3.0 \%)$ and tribeswomen (2.8\%). In this study, females were found to have a higher body mass index (BMI) as compared to males. ${ }^{[7]}$

Some other studies had also been conducted for assessment of prevalence of the risk factors of diabetes in tribal area. A study carried out in Mishing tribe of Assam revealed that $86 \%$ reported vigorous physical activity (men $91 \%$, women $82 \%$; $P<0.05$ ). Sixty-eight percent reported to consume unhealthy diet (less than five servings of fruits and vegetables per day), $11 \%$ had abdominal obesity, $16 \%$ were overweight, and 26\% had hypertension. Nonusers of tobacco and those who consumed more fruits and vegetables had higher prevalence of overweight. ${ }^{[8]}$

A meta-analysis done by Upadhyay et al., revealed the prevalence of DM ranging from 0.7 to $10.1 \%$ in tribal population. The prevalence for impaired fasting glucose (IFG) varied from 5.1 to $13.5 \%$ and impaired glucose tolerance (IGT) from 6.6 to $12.9 \% .^{[9]}$

\section{HeAlth SeRvice NeEdS for Tribal AREAS}

It is noteworthy that tribal ancestral lifestyle was dependent on hunting and gathering food together with cultivation of limited food crops. They have now been forced to adopt a lifestyle based on cultivation of different crops and low-wage livelihoods in business, service, and other mixed occupations like mazdoori or labor, etc. Among the investigated risk factors; increasing age, general obesity (BMI), and consumption of liquor were found to have a higher contribution to risk for developing diabetes and hypertension. The incidence rate of type $2 \mathrm{DM}$ and prediabetes are on the increase among these populations. Previously these populations were free of such kind of lifestyle-oriented diseases. But nowadays the lifestyle patterns of these populations follows the rural and urban lifestyles. The reason as quoted above was lack of their own occupation and were forced to adopt new lifestyles resulting in falling a prey to new kind of diseases.

\section{EFFORTS TOWARdS DiABETES PREVENTION AND CONTROL IN TRIBAL AREAS IN INDIA}

Odisha has more than 40 lakh diabetics with incidence ranging from 12 to $16 \%$ in urban areas and 6 to $7 \%$ in rural parts. The remote tribal-dominated districts of Odisha have also marked an alarming rise in diabetes burden. The Odisha government has equipped district hospitals with advanced diabetes diagnosis equipment and facilities for the same. ${ }^{[10]}$

The Tribal Leaders Diabetes Committee (TLDC) provides leadership, guidance, and recommendations to the Indian Health Service (IHS) on issues related to diabetes and related chronic health conditions among American Indians and Alaska Natives. The TLDC was created in 1998 in response to the successful partnership between IHS and tribal leaders in establishing the process for distributing the Special Diabetes Program for Indians' funds. It makes recommendations on diabetes-related policy and advocacy issues; provides advice and guidance to ensure that appropriate cultural traditions and values are incorporated in program development, research, and community-based activities; and offers guidance to other organizations. ${ }^{[11]}$

Government of India launched National Program for Prevention and Control of Cancer, Diabetes, Cardiovascular Diseases and Stroke (NPCDCS) in January 2008 (revised later) for the control of noncommunicable diseases (NCDs), and this opportunity may be utilized to strengthen activities against diabetes in tribal areas. ${ }^{[12]}$

\section{RESEARCH GAPS IN TRIBAL AREAS}

All India Institute of Diabetes and Research and Swasthya Diabetes Hospital have developed models to improve access to diabetes education, prevention, and care in three distinct settings - rural districts, tribal blocks, and among the urban poor - in India and China. The project 
focuses largely on the parts of western Gujarat and Maharashtra where tribal population density is high. ${ }^{[13]}$ India Health Study, funded by National Institutes of Health, is a feasibility study for a prospective cohort in Delhi, India; which involves evaluation of conducting chronic disease and diet research in India and detailed characterization of the Indian diet. ${ }^{[14]}$ Many such efforts from the various stakeholder agencies targeting both diabetes and other NCDs are much needed, specifically in tribal areas.

\section{CONCLUSION}

Prevalence of diabetes in tribal areas ranges from around 1 to $10 \%$. Intensive efforts directed towards filling the gaps in awareness levels, further surveys, and the operational research or other data or service gaps are required to prevent and control the problem of diabetes in tribal areas.

\section{Financial support and sponsorship}

Nil.

\section{Conflicts of interest}

There are no conflicts of interest.

\section{REFERENCES}

1. Census India 2011. Government of India, Ministry of Home Affairs. Available from: http://censusindia.gov.in/ Census_And_You/ scheduled_castes_and_sceduled_tribes.aspx [Last accessed on 2015 Jun 18].

2. Ramaiya KL, Kodali VR, Alberti KG. Epidemiology of diabetes in Asians of the Indian subcontinent. Diabetes Metab Rev 1990;6:125-46.

3. Ministry of Tribal Affairs, Government of India May, 2014. Report of the high level committee on Socio-economic, Health and Educational status of Tribal Communities of India. Available form: http:// www. indiaenvironmentportal.org.in/files/file/Tribal\%20 Committee\%20Report,\%20May-June\%202014.pdf. [Last accessed on 2015 Jun 18].
4. Ministry of Tribal Affairs, Government of India. Annual Report 20132014. Available form: http://tribal.nic.in/WriteReadData/CMS/Do cuments/201407280104442396450AnnualReport2013-14.pdf. Page 39-40 [Last accessed on 2015 Jun 18].

5. Chaturvedula R, Vishnu, Rampure D, MBV, CUB, CRPS K. Anthropological status and prevalence of Type 2 Diabetes Mellitus in tribals and non-tribals of khammam district of Andhra Pradesh - Interim report. Int J Res Health Sci [Internet] 2014;2:335-9.

6. Kapoor D, Bhardwaj AK, Kumar D, Sunil Kumar Raina SK. Prevalence of Diabetes Mellitus and Its Risk Factors among Permanently Settled Tribal Individuals in Tribal and Urban Areas in Northern State of Sub-Himalayan Region of India. Int J Chronic Dis $2014 ; 2014$.

7. Bandana S. Community based study on incidence of type 2 diabetes and hypertension among nomad tribal population of Rajasthan, India. Intl Jour Sci Nat 2011;2:296-301.

8. Misra PJ, Mini GK, Thankappan KR. Risk factor profile for non-communicable diseases among Mishing tribes in Assam, India: Results from a WHO STEPs survey. Indian J Med Res 2014;140:370-8.

9. Upadhyay RP, Misra P, Chellaiyan VG, Das TK, Adhikary M, Chinnakali $P$, et al. Burden of diabetes mellitus and prediabetes in tribal population of India: A systematic review. Diabetes Res Clin Pract 2013;102:1-7.

10. Government to Take Fight against Diabetes to DHHs. The New Indian Express; $31^{\text {st }}$ March 2015. Available from: http://www. newindianexpress.com/states/odisha/Government-to-Take-Fightagainst-Diabetes-to-DHHs/2015/03/31/article2739253.ece. [Last accessed on 2015 Jun 18].

11. Tribal Leaders Diabetes Committee [document on the Internet]. Washington DC: National Indian Health Board; 2004 [cited 2015 Jun 7]. Available from: http://www.nihb.org/tribal_resources/tldc. php. [Last updated on 2015 Jun 10].

12. National programme for prevention and control of cancer, diabetes, cardiovascular disease and stroke (NPCDCS). Government of India, Ministry of Health and Family Welfare. Last Updated June 17, 2015. Available from: http://mohfw.nic. in/index1.php. [Last accessed on 2015 on Jun 18].

13. All India Institute of Diabetes and Research. Together on Diabetes. Bristol Myers Squibb Foundation. Copyright @2012 Bristol-Myers Squibb. Available from: http://www.bms.com/togetherondiabetes/ china-india/partners/Pages/ all-india-institute-of-diabetes-andresearch.aspx. [Last accessed on 2015 May 05].

14. Centre for Chronic Disease Control. Completed Projects. Copyright (c) 2015 CCDC. Available from: http://www.ccdcindia. org/completed-projects.php. [Last accessed on 2015 May 27]. 